\title{
Reversing the gaze: West Africa performing the EU migration-development-security nexus
}

Introduction

Marie Deridder, Lotte Pelckmans and Emilia Ward

\section{OpenEdition \\ Journals}

Electronic version

URL: https://journals.openedition.org/anthropodev/938

DOI: 10.4000/anthropodev.938

ISSN: 2553-1719

Publisher

Presses universitaires de Louvain

Printed version

Date of publication: 1 December 2020

Number of pages: 9-32

ISBN: 978-2-39061-078-6

ISSN: 2276-2019

Electronic reference

Marie Deridder, Lotte Pelckmans and Emilia Ward, "Reversing the gaze: West Africa performing the EU migration-development-security nexus", Anthropologie \& développement [Online], 51 | 2020, Online since 01 June 2021, connection on 31 January 2022. URL: http://journals.openedition.org/anthropodev/938 ; DOI: https://doi.org/10.4000/anthropodev.938

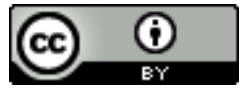

La revue Anthropologie \& développement est mise à disposition selon les termes de la Licence Creative Commons Attribution 4.0 International. 


\title{
Reversing the gaze: West Africa performing the EU migration-development-security nexus
}

Introduction

\author{
Marie Deridder ${ }^{1}$, Lotte Pelckmans ${ }^{2}$ et Emilia Ward ${ }^{3}$
}

This special issue ${ }^{4}$ empirically investigates how EU securitization and management of migration, implemented through the channels of development aid, have gained (or not) traction in francophone West African contexts. The contributions to this issue accentuate the perception of the so-called migration-development-security nexus as seen from the "South". Describing, deconstructing and criticizing the EU policy framework by having an ethnographic focus on West Africa, and the Sahelian countries in particular, such as Mali, Mauritania, Burkina Faso and Niger, is extremely relevant given their "new" geopolitical importance for the EU and its strategy for the African continent. Indeed, since 2011, the EU itself considers that "the successes and failures of the EU Strategy for the Sahel could inspire the whole EU development and security policy on the continent" (Pichon, 2020). The stakes are set for both the present and the future. The central question this issue then tries to answer is how this migration-development-security nexus is perceived, confronted, contested, internalized, experienced and performed once it takes root and is implemented in the daily lived realities of West African actors. The contributors unanimously show that this nexus involves a plethora of heterogeneous actors operating on the ground, having different agendas and understandings of the current issues. They are no longer limited to institutional actors and thus blur a little more the line between public and private sectors. This issue analyzes how this nexus shapes socio-economic and political realities at different levels; (re)produces inequalities between countries,

\footnotetext{
${ }^{1}$ Post-doc researcher in social anthropology and lecturer, Laboratory for a Prospective Anthropology, UCLouvain, Belgium; marie.deridder@uclouvain.be

${ }^{2}$ Associate professor, Centre for Advanced Migration Studies (AMIS), University of Copenhagen, Denmark; pelckmans@hum.ku.dk

${ }_{3}^{3}$ Alumna, Master Humanities, Centre for Advanced Migration Studies (AMIS), University of Copenhagen, Denmark; psw837@alumni.ku.dk

${ }^{4}$ We wish to express our gratitude to Leah Ann Durst-Lee for her proofreading and language revisions. We also thank Paolo Gaibazzi, Jacinthe Mazzocchetti, Anaïs Ménard and Martin Lemberg-Pedersen for having commented on earlier versions of this draft, as well as the anonymous reviewers of the contributions to this issue. We also thank the contributing authors and the Editorial Board for their patience, insightful comments, and support throughout the publishing process.
} 
institutions and people; impacts mobility and settlement dynamics; and, more globally, increases vulnerabilities and violence. The articles in this special issue contribute to emerging literature that decenters the locus of analysis to focus instead on places which are usually understood as "transit" or "sending" countries in a Eurocentric way (see also Stock et al., 2019).

We think that this emic accent, and the flipping of the usual European gaze on Africa, are important in order to counter the proliferation of reports on EU externalisation of security and migration policy in/on the African continent written by journalists, selfproclaimed specialists and think-tanks adopting a macro and policy-oriented (i.e. "problem" solving) approach. A non-exhaustive list of examples includes Paula GarciaAndrade et al. (2015) for EU; Alexandre Devillard et al. (2015) for the Swiss Agency of Development and Cooperation; Bernardo Venturi (2017) for both the Foundation for European Progressive Studies (FEPS) and the Institute of Italian Affairs; Matthieu Tardis (2018) for the Center for Migration and Citizenship at the French Institute for International Relations; and Rahmane Idrissa (2019) for the German Friedrich Ebert Stiftung. This introduction, as well as several contributions to this issue, clearly illustrate how this approach is problematic for multiple reasons. First, such reports often neglect actual practices and their performative significance for policy outcomes and results, thus moving beyond discursive intentions and sensationalist rhetoric. Indeed, macro-approaches tend to focus on policies and solutions, but seem to systematically bypass and underestimate the relevance of including more complex micro-realities of the actual reception, processing and performative effects of outsourced EU policies by a range of African actors on a daily basis. Secondly, the presentism of these studies is rather problematic in that they do not address important historical continuities in the ways in which former colonies explain their contemporary interventions in African contexts. Many of these reports excellently map and describe the EU policies and analyze the different imbrications of development, security and migration in a newly declared nexus, while failing to recognize and flesh out historical connections. Thirdly, several of these reports are commissioned by particular institutions that are highly implicated in the phenomena they analyze, with severe risks of engaging in circular arguments that are self-promoting and also connected to self-serving economic interests of national and commercial actors, as analyzed below. Finally, even though some of these reports promote the "urgent need for coherent, more evidence-based and less fear-based policy-making" (Raineri and Rossi, 2017), actually finding and generating evidence-based material seems to be challenging. In other words, views "from below" (Bayart et al., 2008) have not only been overlooked, but their value has been underestimated for policy purposes in general. Also, in academic debates, statecentric views often dominate.

We argue that these tendencies towards presentism, economic rationales, and macro overviews have contributed to a current gap in the mushrooming literature on the outsourcing of EU migration policies in francophone West Africa: namely a lack of studies addressing the historical continuities and/or working with case material grounded in daily performances, interactions and emic perceptions by the African actors involved. This lack is also a result of the increased security risks for those doing research "from 
below" (Hagberg, 2018) in contexts such as Mali, Burkina Faso, Libya, Mauritania or Niger, that are marked by high insecurity and conflicts, and which are flagged as no-go "red zones" by Western governments. In view of ministerial decrees and embargos against visiting countries, many non-national qualitative researchers have opted for safer countries and places, and/or have reoriented their fieldwork towards the Sub-Saharan African diasporas in North African and Western countries. At the same time, increasing demands for commissioned consultancy work, often go to the detriment of qualitative and longitudinal work. The insecurity in the region has also opened the doors to the overrepresentation of national and international experts' speculations on "root causes" and "solutions". This over-representation and over-research of the same handful of politically salient displacement crises are linked to the aforementioned self-serving political and economic interests facilitated by humanitarian supply or security supply chains (LembergPedersen and Haioty, 2020; Pascucci, 2017).

This begs the question of the extent to which dissident, subaltern and emic voices of those not making policy, but implementing and/or experiencing policy, are adequately represented in current scientific literature. We argue that such voices are lacking and we therefore have invited papers in which actors in and from Africa vocalize how they have adapted, responded, questioned, relativized or even contradicted the hegemonic EU perception of a hardcore "migration-security" crisis.

The focus of this issue is thus to redirect the gaze towards the daily interactions surrounding EU policies once they become implemented in francophone West African contexts, where local tactics and performances are mutually re-shaping Eurocentric ideologies, policies and registers of "crisis". The contributions ${ }^{5}$ all foreground a plethora of African engagements and demonstrate, in how many different ways, EU policy talk can be performed and grounded in everyday complexities. The interlocutors central to these contributions speak back to the dynamics and discourses of development, migration and security, and demonstrate that the hegemonic Eurocentric ideas are optimistic at best and sensationalist, as well as failing reality, at worst.

In the remainder of this introduction, we describe, deconstruct, and highlight the buildup of EU-West Africa relations in the field of migration and security over the past two decades (from 2001 onwards). First, we discuss the evolution of global policy framings from a migration-development nexus towards a migration-development-security nexus, that have led to an increase in coercive measures. In the second section, we address some of the major ideological and performative issues underlying this nexus, namely that migrants, terrorists, and people in a state of precarity seem to have merged into one single threatening figure of Otherness. We then discuss the problematic racialized stereotypes broadcast by the media that often come with crisis discourses and politics of

\footnotetext{
${ }^{5}$ Some of the important insights made by the contributors to this special issue resulted from two panels organized by the editors, for the APAD conference in Denmark (Roskilde) on Migrations, Development and Citizenship in 2018.
} 
fear on both continents. Finally, we recall how the asymmetrical and racialized power relations between Europe and Africa are historically rooted in racialized capitalism and in colonial imperialism. In the third and last section, we present the contributions to this special issue, while our concluding remarks underline how we can observe the creation of "EurAfrican" borders (Gaibazzi et al., 2017). New issues, practices, subjects, places, as well as new collective and individual subjectivities, emerge from this migration-developmentsecurity nexus that question Eurocentric responses to migration which tend to narrow it down to either security and/or humanitarian needs.

\section{From a migration-development to a migration-development-security nexus in EU-Africa international relations: a global policy framework}

In this section we explore the genealogy/evolution from a migration-development nexus towards a migration-development-security nexus in a global policy framework largely promoted by the EU. ${ }^{6}$

Historically, the creation of migration policy at the European level has been articulated within the closure of European countries' legal access to labor migration since the 1970s (Dedieu, 2018). Since then, the EU has focused on selective migration and the implementation of filtering policies fostering high-skilled worker programmes and student exchanges. In the 1990s, the policy of free movement and the creation of the Schengen area led to the harmonization of controls at the EU's external borders, as well as the implementation of readmission agreements signed between the EU and third countries. These agreements facilitate enforced expulsions of undocumented migrants. Article 13 of the Cotonou Agreement, signed in 2000 between the EU and 79 countries from Africa, the Caribbean and the Pacific (ACP), explicitly links cooperation agreements and migration control policy. Over the past two decades, migration has become a central feature in negotiations between European and African countries, including in areas that are not historically linked to migration policy, such as trade, development and security (Gabrielli, 2007; Dedieu, 2018). As Marie-Dominique Aguillon (2018: 8) points out, "with the Cotonou agreement, it is the first time that an instrument of economic cooperation financed by [...] Official Development Assistance [...] contains questions related to the removal of individuals in an irregular situation". Thus, the EU's international partnerships have grown increasingly founded upon a double principle of inclusion and exclusion.

The 11 September terrorist attacks in New York, followed by those in Madrid in 2004 and in London in 2005, were a global tipping point for both security and migration responses worldwide. Since then, the USA and the EU have pro-actively integrated West Africa into their "Global War on Terror". In line with the so-called radicalization of "Islamist terrorist groups", the perceived "terrorist threat" emanating from Sub-Saharan Africa is mainly constructed around categories - "weak", "fragile", "failed", "collapsed" -

\footnotetext{
${ }^{6}$ Monitoring and documentary analysis by Marie Deridder since 2015 as well as fieldwork and interviews
} in 2017 in Bamako on the negotiation of the EU "new Partnership Framework" policy. 
which stereotype and hierarchize African states. Such "discourse of 'state failure' legitimizes interventions by identifying lack, inferiority and incapacity" (Gruffydd Jones, 2008: 197), thus reconnecting with the colonial legacy of imperialism. As a result, African governments were co-opted into a USA-EU transnational militarized security complex (Vaughan-Williams, 2008; Keen and Andersson, 2018). This involved closer military cooperation between North, West and East African states - mapped by some as the socalled "arch of terrorist activity" (Crawley and Blitz, 2019) - with a special focus on securing borders and establishing biometric surveillance systems, as well as strengthening intelligence networks and military bases (e.g. in Chad, Niger, and so on). In 2004, the EU created Frontex, an agency mainly military in form, tasked with managing EU borders. Since then, the EU earned the sordid name of "Fortress Europe".

Then, in September 2005, the drama of Ceuta and Melilla hit the headlines when Moroccan and Spanish police killed a dozen migrants and injured more than a hundred caught in a crossfire at the border fence in the Spanish North African enclave. Following this, at the end of 2005, the EU adopted its "Global Approach for Migration and Mobility" (GAMM), focusing on Africa and the Mediterranean. At that time, the EU underlined the need "to combat illegal immigration" and "tackling the root causes of migration" in "cooperation with third countries", which were, "in particular, the regions neighbouring the Union, namely the eastern, south eastern and Mediterranean regions" (European Council, 2005: 3). Emphasis was also placed on "return management, in a spirit of partnership" (European Council, 2005: 3). In this communication, the EU did not yet frame migration and counter-terrorism as one single issue. Moreover, its strategies were based on the assumption that migration was mainly driven by economic incentives. The "eradication of poverty in countries and regions of origin, the opening of markets and promotion of economic growth, good governance and the protection of human rights" (European Council, 2005: 3) were supposed to be the recipes for tackling emigration. Policies promoting grassroots development to stem emigration came to be regarded as "best practices" and were emulated around the world (Iskander, 2010). As Sadio Soukouna (this issue) illustrates with Malian case material, this was the heyday of codevelopment, mainly promoted by France in West Africa (Daum, 2007; Courtin, 2007).

In 2006, France, Morocco, Senegal, and Spain gave the impetus to the Rabat Process, with the first Euro-African Ministerial Conference on Migration and Development bringing together 58 countries, the European Council, ECOWAS, and observer organizations. According to the official rhetoric on the Rabat Process' website", the aim is "to openly discuss migration and development issues in a spirit of partnership and shared responsibility". The Rabat Process affirms to be "a dialogue platform for national administrations of the countries of origin, transit and destination along the West African migration routes". Its self-imposed mission is to find "a response to unmanaged migration flows", which "required a coordinated response from all concerned countries". ${ }^{8}$ Since then, policy

\footnotetext{
${ }^{7}$ https://www.rabat-process.org/en/ (accessed July 2020)

${ }^{8}$ https://www.rabat-process.org/en/about/rabat-process/333-rabat-process (accessed July 2020)
} 
instruments and bi- or multilateral agreements are negotiated directly by member states, or by the EU itself with third countries. The EU framework to manage migration, cooperation and "dialogue" with third countries, notably African countries, is characterized by a technocratic approach guided by a principle of "partnership" that depoliticizes and artificially overshadows historical and racialized relationships of deeply asymmetrical interdependence between countries of the North and the Global South (Geiger and Pécoud, 2010; Pécoud, 2015, 2017; Kunz, 2013; Lavenex and Kunz, 2008). The framework promotes "indisputable objectives" of security, humanitarianism and economic progress and claims that it acts "for the benefit of all parties" (Pécoud, 2017: 83; Aguillon, 2018: 6). However, Antoine Pécoud (2017: 83) reminds us that throughout their history, these global initiatives and, notably, the International Organization for Migration (IOM) are "politically aligned in [their] mode of operation and activities on the agenda of the Western countries and the priority they give to the control of migration flows". Moreover, as Martina Tazzioli and William Walters (2019) have underlined, even when the EU political lexicon refers to solidarity for migration issues, it is with the particular meaning of burden-sharing of refugees through its internal and external policy. Additionally, the EU promotes and finances public campaigns and civil society initiatives in third countries to tackle "unwanted" departures, described in detail by Aguillon (this issue) for Senegal. She shows how these initiatives frame the public debate and the narratives of a broad range of actors, even those with a critical stance. Therefore, a wide variety of development and civil society actors have become active in what is often termed the "security-development nexus", giving way to new assumptions, causal links, and policy instruments on how to prevent departure, organize deportation, as well as stabilize and manage (semi-post) conflict societies in Africa and in the Global South more generally. In the span of a decade, migration and terrorism have progressively walked hand in hand and are thus currently at the very heart of this migration-development-security nexus when it comes to EU-Africa international relations and foreign policy.

A decade later, the 2015 influx of refugees/migrants coming from the Middle East, Africa and Asia into Europe has strengthened the rising European rhetoric of the "migration crisis". Since then, despite a drastic drop in the number of migrants arriving on European territory according to the UNHCR", the EU has not changed its discourses. The "crisis" rhetoric and the language of security (securitization) has had far-reaching consequences, often deadly for the refugees and migrants involved, and has resulted in implementation of several policies linking migration, development and security in West Africa. Rebranded as part of the European "neighborhood", and under the guise of heightened investments in development cooperation, the EU's development budgets and instruments are used in West Africa (and elsewhere) to "curb" and "halt" migration "flows", "settle" Sub-Saharan populations, and prevent departures of "unwanted" or "undesirable" migrants "at the source", that is, in so-called "transit" or "origin" countries. This has mainly been done by resorting to using development money for implementing expensive high-tech control

\footnotetext{
${ }^{9}$ https://data2.unhcr.org/en/documents/download/63039 (accessed July 2020)
} 
mechanisms (biometric data, security scanning and online databases), in combination with upscaled armed controls by the military, police and other security actors. The lexicon of the "migration crisis" in the EU "motivates" this increased military presence in EU "neighborhoods", even though the main targeted African countries are more than 5,000 kilometers away from the EU's external borders. The issues of migration, development and security have come into focus as the major political problems, prompting discourses, policies and "dispositifs de crise" (Bonnecase and Brachet, 2013). The terrorist attacks in Paris and Bamako in 2015, as well as in Ouagadougou and Brussels in early 2016, have contributed to these narratives. In a country like Mali, the "fear of terrorists" has resulted not only in armed guards of expensive private companies ${ }^{10}$ at every establishment catering to expats and elites in the capital city, but it has also reinforced the legitimacy of diverse armed "self-defense" groups and an increasing tolerance for deadly modes of conflict solving (Hagberg, 2019).

In November 2015, the EU-Africa Valletta Summit ${ }^{11}$ in Malta constituted a second tipping point that catalyzed this migration-development-security nexus. At this summit, the EU explicitly defined its priorities for Africa by linking migration, development and security through the combination of different key policy elements like "development aid, trade, mobility, energy, security, digital policy" (European External Action Service, 2016). Since this summit, the EU has been working on its new "Partnership Framework with third countries under the European Agenda on Migration" with a special focus on "priority countries of origin and transit" (European Commission, 2016a). In West Africa, those "priority countries" are Mali, Nigeria, Niger, and Senegal.

Quoting European rhetoric, these "partnerships" are not summarized in a single document but entail "a series of provisions and exchanges between the European side and the African side [...] to decouple readmission agreements and legal migration to Europe so that the domestic problems connected with the two issues do not block each other" (Toaldo and Barana, 2016). The "partnerships" are realized through the negotiation of bilateral tailor-made "compacts", including readmission agreements. Increasing the numbers of returns and readmissions - in other words, increasing deportations - is a key component of this policy (European External Action Service, 2016: 1). According to the EU's rhetoric, "the compacts approach avoids the risk that concrete delivery is held up by technical negotiations for a fully-fledged formal agreement" (European Commission, 2016b: 3). Reconnecting with tied aid in development cooperation, "a mix of positive and negative incentives" are integrated into those political frameworks "to reward those countries willing to cooperate effectively with the EU on migration management and ensure there are consequences for those who refuse" (European Commission, 2016a: 2). The EU rhetoric specifies that "there must be consequences for those who do not

\footnotetext{
${ }^{10}$ Fieldwork and interviews with some of these private security companies in Bamako, by Lotte Pelckmans in 2016.

$11 \mathrm{http} / / /$ www.consilium.europa.eu/fr/meetings/international-summit/2015/11/11-12/ (accessed July 2020)
} 
cooperate on readmission and return. [...] migration cooperation should be a consideration in the forthcoming evaluation of trade preferences under 'GSP+'" (European Commission, 2016c: 9).

Then, the "European Union Emergency Trust Fund for stability and addressing root causes of irregular migration and displaced persons in Africa" (EUTF for Africa) was formally launched at the Valletta summit. It provides additional funding to support the implementation of the action plan in Mali, Nigeria, Niger, Senegal, and Ethiopia. From 2016 to date, this EUTF for Africa finances a large variety of projects accomplished through aid conditioning (Schöfberger, 2019). Recalling colonial days, this approach justifies the handing over of development aid to both help and "fix" people on the African continent. In the name of human rights and security, everyone should accept a strengthening of coercive measures. Instead of the development of "the ordinary citizen" for whom it was intended by, for instance, creating job opportunities, the funding is in practice mainly being allocated and used for funding security-focused projects. These include the training of police, border guards and intelligence services, as well as the biometric identification of African citizens, in turn allowing for future tracing of potential terrorists, smugglers (Awenengo et al., 2018) and "undesirable" citizens. This has paved the way for the strengthening of legal, administrative and juridical mechanisms allowing African governments to increase their performance of sovereignty through monopolies on deportation, imprisonment and the criminalization of migrants and people involved in "the work of migration" in their countries. As the contributions in this issue of MarieDominique Aguillon, Florence Boyer with Bachirou Ayouba Tinni and Harouna Mounkaila, Alizée Dauchy, Hassan Ould Moctar, and Almamy Sylla show for the cases of Senegal, Niger, Mauritania and Mali, the EUTF framework has not only problematized longstanding histories and networks of migration, but it has also contributed to severely criminalizing them. Indeed, a large range of actors, such as private bus companies, are now participating in the implementation of such coercive measures even if there is no real consensus on their actual aims. Furthermore, as Aguillon (2018, this issue) and others (Bouilly, 2008; Pian, 2014) have explained, new causal links have appeared in EU narratives and percolated into civil society actions on the African continent: the return of some migrants is supposed to prevent the departure of new candidates to migration. This "emigration dissuasion" has become a new funding niche (Aguillon, 2018, this issue) whereby awareness campaigns encourage "staying at home", reintegration programs are set up for "returnees", and "success stories" are defined as a failed trip followed by a successful reintegration at home. On paper, the EUTF for Africa addresses a "series of challenges" such as "open conflict, forced displacement, irregular migration, criminal activities and lawlessness, smuggling of migrants and trafficking in human beings, radicalization and violent extremism". ${ }^{12}$ In reality, however, the EUTF has channeled development funding towards security and defense mechanisms and materials (Den Hertog, 2016). Combining all of these challenges into one single EUTF fund illustrates the seemingly unproblematic

\footnotetext{
${ }^{12}$ https://ec.europa.eu/europeaid/regions/africa/eu-emergency-trust-fund-africa_en (accessed July 2020)
} 
linkages/conflation between development, security and migration and the resulting depoliticization of each of these three core challenges.

Moreover, besides the initiatives supported by the EUTF, the EU has developed the EUCAP Sahel, which was officially launched in Niamey and Bamako at the request of local governments in 2012 and 2015, respectively, to focus on "strengthening local capacity for maintaining security". According to the official rhetoric on their website, their mission includes "border management" and explicitly links the fight against terrorism, traffickers, smugglers, and migration into a single "common" security perspective. EUCAP Sahel is part of the European Common Security and Defence Policy (CSDP). ${ }^{13}$ Work is mainly carried out through advising, training and mentoring West African counterparts. Here again, this illustrates how the existing articulations between development and migration have been drastically redefined by security concerns. As a result, also in Africa, commercial security actors and technologies have become much more prominent and visible. For instance, the 2019 edition of ShieldAfrica, a major bi-annual international meeting point for security and defense actors, with the latest global high-tech arms on display, in Abidjan was themed: "protection and control of borders" ${ }^{14}$ This illustrates how the political and economic incentives for "development initiatives" cater to commercial interests in export markets for European border and anti-terror equipment (Lemberg-Pedersen, 2013, 2019) rather than actual conditions and needs of West African citizens. However, despite the hard-core economic prominence of security companies and high-tech solutions, the language chosen to persuade citizens emphasizes soft concepts, like "development", the spread of "human rights", "peace-keeping" and "conflict prevention".

Both in terms of economic markets and geopolitics, the EU has clearly enlarged its "neighborhood" southwards into the African continent. While in the 2000's the EU still mainly focused on cooperation with the Mediterranean region and Northern African countries, from 2010 onward the so-called "transit countries" in Sub-Saharan Africa (both East and West) were included as part of this European "neighborhood". Countries such as Niger and Mali have become laboratories for the outsourcing of the EU policy framework through so-called hotspots, which necessitated significant rebranding of these countries as "transit countries" (Bredeloup, 2012; Collyer and De Haas, 2012). This re-categorization has had far-reaching consequences for movements of both nationals and migrants in these countries, who can at any time be accused of "probably being on their way to Europe" and on the basis of such suspicion can be arrested, transferred, detained and/or deported. To that end, military control units in Sahelian countries, originally established to fight Al Qaeda and Boko Haram, are now funded by development money as units that assist in "curbing" migration. Security personnel trained to contain and control terrorist activities now have an extended mandate to "capture" smugglers and transit migrants.

\footnotetext{
13 https://eeas.europa.eu/topics/common-security-and-defence-policy-csdp/49730/part-4-eu\%E2\%80\% 99s-civilian-missions-around-world_en (accessed July 2020)

${ }^{14}$ https://news.abidjan.net/h/651445.html (accessed July 2020)
} 
The goal is to curb migration towards Europe rather than addressing structural inequalities in the Sahel (Schöfberger, 2019).

Existing intra-African migratory and commercial systems stemming from the long-term history of exchanges between the Sahelo-Saharan zone (Bredeloup and Pliez, 2005; Bensaâd, 2009; Brachet, 2009; McDougall and Scheele, 2012; Eizenga, 2019) have been severely changed, interrupted and altered by these EU "neighborhood" policies and "transit" discourses. EU policies have de facto challenged free movement agreements within the West African economic union of ECOWAS and have clearly affected and securitized African discourses, practices, and policies (Kabbanji, 2013).

Ironically, this heavy emphasis on security ultimately fails to mitigate migration, but instead pushes migrants into increasingly marginalized positions, causing them to take more dangerous routes, paying higher fees for transport, and so on. Giacomo Orsini's observations for Lampedusa also work for African contexts: "the cure - more security seems to generate the symptoms - more insecurity" (Orsini, 2016: 145). The fight against terrorism clearly exacerbated internal displacements resulting from political instability thus encouraging migration - and, as such, created a circuit of ever denser cycles of precarity that are used to justify greater security interventions (Crawley and Blitz, 2019; Keen and Andersson, 2018). As a result, irregular migration and moving people have become "naturally" criminalized, justified by potential connections with smugglers, if not outright terrorists. Similarly, the global fight against terrorism obscures the fact that some "radical" movements engage in visible violence against their national governments in order to claim more egalitarian, legitimate and inclusive governance in specific regions (e.g. Northern and Central Mali) and sectors (e.g. national security, education, justice...). To conclude, within a short timeframe, not only concerns of development and human rights, but also security, have been invoked to justify and legitimize massive sovereigntybreaching policies by the USA and EU on African territories. This migration-developmentsecurity nexus (Sørensen, 2012; Truong and Gasper, 2011) is indeed a merging of the former migration-development nexus (Dedieu, 2018) with a more recent migrationsecurity nexus (Faist, 2006).

\section{From blind spots to hotspots: the racialized "Other" and Western colonial amnesia}

In this section, we address some of the major ideological and performative issues of this migration-development-security nexus on both European and African continents, namely the ongoing representation of people in a state of precarity as criminals, and the ways in which mostly African migrants and terrorists seem to have merged into one single threatening racialized figure. Then, to counter an ahistorical understanding of these issues, we wish to recall how the asymmetrical power relations between Europe and Africa are historically rooted, entangled and shaped by both racialized capitalism and colonial imperialism. 
Although subject to extreme inequalities on a global scale, the attractiveness of (long distance) migration has increased through the accessibility and sharing of transnational imaginaries in a globalized and postcolonial setting (Vigh, 2009; Jackson, 2008; Kleist and Thorsen, 2017). These imaginaries are associated with success and modernity, contrasting sharply with national contexts characterized by an "absence of possibilities" (Mazzocchetti, 2009; Bréda et al., 2013), which is quite predominant in Sub-Saharan Africa. Over the past fifty years, imaginaries of human mobility and migration have been profoundly refined but also politically transformed. On the one hand, there is a body of humanitarian rationales, which focuses on suffering and the need to securitize migrants as passive victims (Agier, 2008, 2013; Fassin, 2010; Ticktin, 2014). On the other hand, both on the European and African continents, people on the move are increasingly disqualified with allegations of opportunism, duplicity and undeservingness, accentuating xenophobia based on exclusive claims to autochthony, nationality and ethnic belonging (Nyamnjoh, 2006; Geschiere, 2009). On both continents, those "unwanted" and "undesirable" migrants are often perceived as illegitimate because governments and the media claim them as a threat to national sovereignty and belonging. The first main effect of this migration-development-security nexus is thus the reinforcement of the (would-be) migrants as a threatening "Other" with dangerous political consequences.

Similarly, the fear for terrorism and the global fight against terrorism have lately received overwhelming attention, both in the form of crisis discourse and financial support. From the early twentieth century onwards, Africa was presented as an unimportant geopolitical actor in Western discourses. The continent was mainly perceived as either a place of economic extraction (oil from Nigeria, fish from Senegal, uranium from Niger, gold and cotton from Mali) or one of suffering and in need of assistance, with occasional crises peaking during the 1970's and 1980's droughts, reviving international compassion, solidarity and humanitarian and development aid. Remote regions were neglected as blind spots in both international and national politics. Today however, with borders gaining prominence, former blind spots seem to have turned into hotspots.

Both migration and terrorism have thus proven to be incredibly strong vectors around which emotion are mobilized, resulting in a politics of fear (Nussbaum, 2018). Migration and terrorism have become the main political issues in both global political agendas and national politics. Both African and European politicians have deployed manufactured rage (Mehta, 2019) against migrants, stemming from the fear of identity loss, to justify curtailing civil liberties for the sake of security. The proposed solutions on both continents to the so-called "migration-security crisis" have led to policy choices which focus more on short term solutions to develop a security apparatus, as well as to "manage" the precariat, rather than addressing precarity as a structural and political condition (Mazzocchetti, 2018). The so-called "migration crisis" therefore also indicates the flaws of the neoliberal project, in particular, the gaps between the promoted ideologies (freedom, mobility, meritocracy, consumption and individual success) and a system with deadly effects for a large proportion of the world's populations from formerly colonized countries (Ferguson, 2002). 
Despite EU policies' discursive emphasis on development and human rights, irregular migrations from Africa are paradoxically constituted by, and rooted in, stringent EU-driven security policies negating rather than diminishing blatant socio-economic inequalities. EUhelmed security initiatives result in the risk-transference of violence and political instability to subjects with the lowest stake in such interventions - namely, ordinary citizens (Keen and Andersson, 2018). Indeed, most EU policies have so far proven extremely lethal to migrants, leading to thousands of deaths both in the Saharan desert (Brachet, 2010, 2011 and 2018; Lecadet, 2016) and the Mediterranean Sea (Heller and Pécoud, 2018; Stierl, 2016; Schmoll et al., 2015). They have thus clearly exacerbated precarity while on paper and vis-à-vis the European audiences mitigating it. Moreover, these deaths feed the politics of fear and the perceived need for more security, thus turning into a vicious cycle, if not a self-fulfilling prophecy.

By linking the figure of the poor to that of the potential migrant, and the figure of the migrant to that of the smuggler or terrorist, a cyclical loop is achieved by overlapping stereotyped figures which link poverty with mobility and terrorism. These figures are systematically underlined in the common imagination as the ultimate symbols of crisis in both Africa (Bonnecase and Brachet, 2013) and Europe (Campesi, 2018). A second major effect of this migration-development-security nexus is thus the conflation of these figures into one single threat to both Europe and Africa, which serves as a strong ideological justification for the new forms of cooperation between humanitarian and development organizations, as well as defense and intelligence forces, and results in often highly problematic "issue linkages" (Lemberg-Pedersen, 2013).

Through the brokerage of donors and international organizations who bring both the problems as well as the solutions to the table, these "issue linkages" are translated into public policies negotiated and adopted by some African countries. Several contributions in this issue (Aguillon; Boyer et al.; Dauchy; Lambert; Soukouna) demonstrate just how complex the implementation and the impacts of these policies are. Indeed, the EU "Partnerships Framework" end up working in multiple and not always foreseen directions (Cassarino, 2018). The contributors to this issue demonstrate the need for grounded and in-depth studies of the making of public action on the ground. This includes a focus at different levels and between a plethora of actors, combining implementation in each national context with a transnational approach. With her analysis revolving around the case of Sudanese asylum seekers in Agadez (Niger), Laura Lambert demonstrates the multidirectionality of the effects of the externalization policies. In tandem with the political conjuncture of criminalization of smugglers and terrorists, and knowing about protracted wars going on in Sudan, local citizens and bureaucrats of Niger have accused these asylum seekers of being combatants and war criminals, reflecting more how Nigerien citizens are fed up with insecurity in their own country than real knowledge about the actual profiles of the mobile people accused. Historically these Sudanese groups might have been met with more hospitality based on ideologies linked to legitimate flight from oppressive regimes, as well as based on ideas of the stranger as a potential source of knowledge, connectivity and learning (Bredeloup, 2013, 2017). Nauja Kleist and Dorte Thorsen (2017) stress that, despite the well-known risks associated with irregular 
migration, African migrants continue to deploy long-distance migration as an attractive livelihood strategy, not in spite of the uncertainty, but because of it, since there is hope characterized by the anticipation of an unknown future potentially better compared to the precarious present.

The EU rhetoric has thus reduced this heterogeneity of people on the move to binary oppositions, distinguishing "good" from "bad" migrants, thereby manufacturing the category of "illegal" migrants. It is not only these migrants who are criminalized, but also the people who want to help undocumented (thus "criminal") migrants suspected to be heading to Europe. Solidarity is perceived as facilitating irregular migration and is thus considered a threat that merits criminalization (Tazzioli and Walters, 2019). This binary imaginary induces a sort of generalized "smugglerization" of migration issues (Tazzioli and Garelli, 2018; Tazzioli and Walters, 2019). We indeed witness a highly problematic conflation of terminologies, whereby smuggling is equated with human trafficking, and where all African migrants in Africa are per definition irregular and always in transit, based on the European strategy which "divides Africa into countries of 'transit' and 'origin' of migration in an unapologetically Eurocentric manner" (Korvensyrjä, 2017: 196). Eurocentric understandings of transit are also exhibited in how European states fail to consider the contradictory intra EU mobility regimes, which criminalize some forms of mobility while permitting others (Schapendonk, 2017; Schöfberger, 2019). Though the EU seems to be an integrated, borderless space for its residents, African migrants are constrained by national laws and European outsourcing policies. These representations of the transiting, and therefore criminal, migrant have become mainstream and, in turn, have contributed to legitimizing securitized mechanisms for managing, monitoring and regulating "migration flows" on both continents.

This leads us to the third major effect of this migration-development-security nexus. These representations of the criminal migrant are shaped by the global policy frameworks described above, as well as by media broadcasting racialized stereotypes (D'Haenens et al., 2019) in the present "conjuncture of racism" in Europe (Gutiérrez Rodríguez, 2018: 17). When reading newspapers in Europe, migration from Sub-Saharan Africa to the EU seems to be occurring on a massive scale, even though it remains a minor statistical fact. Most African migrants circulate within Africa, and especially West Africa which has a long history of population movements between countries. However, as Nicholas De Genova (2013) and Ruben Andersson (2014) have outlined, if European media covers migration, it is by repeatedly producing the "border spectacle" of the crossing of the Mediterranean Sea or the English Channel by boat, as well as by imagining the overcrowded camps in Southern and Eastern Europe. At the time of writing the final words of this introduction in September 2020, the overcrowded Moria refugee camp in Greece is on fire. The EU's response is slow in coming and again, this "border spectacle" stages predominantly black and brown bodies in a sordid and lethal setting and points to the idea of rupture and singularity (Gutiérrez Rodríguez, 2018: 19).

By drawing on parallels between colonial practices during the transatlantic slave trade and the current EU border controls, Martin Lemberg-Pedersen (2019) has demonstrated 
how this rhetoric of exceptionality and emergency overshadows strong continuities rooted, entangled and shaped by both racialized capitalism and colonial imperialism. Ould Moctar (this issue) also shows us, with a case study from Mauritania, that this nexus has racialized effects on both continents. In Mauritania, the racial grammar distinguishes between "white Moors" or "white Arabo-Berber", and "black Africans", and it is members of the latter category who can be legally deported. The author explains that colonial knowledge production has contributed to this racialization and has endowed its racial imaginary with territorial legitimacy. Similarly, Sylla's contribution (this issue) on Malian returnees from Libya gives a long-term historical overview of Malians' deportation from Libya, with increased racialization. Sylla also demonstrates how the returnees perceive a differentiated and racialized treatment by their own government (Malian authorities) who, in their view, clearly privileges generally lighter skinned Tuareg communities over the "black African" groups. To counter an ahistorical understanding of the migrationdevelopment-security nexus, we thus urge scholars to recall how the asymmetrical and racialized power relations between Europe and Africa are historically shaped. The racial fact of this so-called "migrant crisis" is seldom acknowledged because it confronts us with the cruel (post)coloniality of Europe (De Genova, 2017: 1766) and its effects on the African continent.

Moreover, far from being a thing of the past, after the EU-Africa Valletta Summit, the EU has explicitly, formally, and publicly invited Member States to use "historical ties" to support the negotiation of bilateral compacts with African countries. EU rhetoric has it that "the special relationships that Member States may have with third countries, reflecting political, historic and cultural ties fostered through decades of contacts, should also be exploited to the full for the benefit of the EU" (European Commission, 2016c: 8). In other words, the EU has encouraged its Member States to mobilize all the instruments, tools and leverages available to pressure African countries into cooperation, with all the violence of coloniality of power (Quijano, 2000) existing between former colonies and metropolises. Lemberg-Pedersen (2019: 20) rightly underlined that "EU externalization visions, while predominantly pursued in formally decolonized contexts, seem built on reoccurring colonial imaginations of space and mobility; and [...] facilitate the reoccurrence of overtly imperial and neo-colonial ambitions".

Contemporary EU practices like naval interception, regional disembarkation, control and arms export to partners, and sorting areas for migrants, starkly resemble similar, but largely ignored, British, American and French practices during the suppression of the transatlantic slave trade in the 19th century. The EU is shamelessly implementing its own para-legal system in rebranded West African "priority countries", by building hotspots, sorting and identification areas, where aspiring refugees will have to get (or not) their asylum granted according to European standards. These new policies, rhetoric, and tendencies resonate strongly with historical patterns of colonial rule, whereby humanitarian and developmental terminology played a key ideological role in justifying paternalistic protection through a monopoly of violence and a permanent breach of local sovereignties. These practices thus exhibit remarkable continuities indicating colonial matrices of power, 
which informs European epistemologies of displacement politics and migration control (Lemberg-Pedersen, 2019).

In short, the current EU-Africa migration-development-security nexus cannot be analyzed as a novelty, nor as a temporal rupture, but rather betrays ongoing continuities over the longue durée. Aino Korvensyrjä (2017) argues that negating this equates with suffering from "colonial amnesia" and the active reproduction of a dominant narrative in EU historiography. The ways in which the current EU framework articulates this migrationdevelopment-security nexus have very striking resemblances to racialized imperialist modes of governance and spheres of influence, even if the contemporary materialities are different. Therefore, this nexus redraws and reinforces the "global colour line" (De Genova, 2017: 1766) that has emerged in past centuries through various segregationist policies.

The contributions to this issue empirically demonstrate how the global policy framework to manage migration "as devices operating within the logic of coloniality [has] a racializing effect" (Gutiérrez Rodríguez, 2018: 20) and directly impacts the construction of SubSaharan migrants' political subjectivities, not only in Europe, but also in Africa. As such, long-term colonial practices of domination and exploitation, which have been continued into the postcolony (Mbembe, 2016), are being reinforced and formally legitimatized in the so-constructed emergency context of the terrorist threat and migration crisis. Nevertheless, as the contributions of this special issue remind us, it is also important for scholars to take into account the agency of African states when analyzing European-led interventions. Turning a blind eye to the ways in which African states actively participate in border security as a social and technical practice in pursuit of state capacity (Frowd, 2018) risks de-politicizing their actions. As the contributions by Elsa Tyszler, Alizée Dauchy and Almamy Sylla in this issue demonstrate, this observation does not erase the increased violence and repression committed in the name of this nexus, but goes to show how it is a global straightjacket.

\section{Reversing the gaze}

This special issue is composed of nine papers based on original and long-term empirical fieldwork data and it demonstrates precisely how local tactics and performances are mutually re-shaping Eurocentric ideologies, policies, and registers of "crisis". Bringing together scholars of anthropology, sociology, political sciences, and development studies, either based in West African countries and/or working with African actors, the contributions allow an empirically grounded inter-disciplinary dialogue on the migrationdevelopment-security nexus. They redirect the gaze towards the daily interactions surrounding EU policies once they become implemented in francophone West African contexts - more specifically Mali, Mauritania, Niger, and Senegal. These countries have been rebranded as "priority countries" and/or are part of the enlarged European "neighborhood". The contributors unanimously show that this nexus involves a wide variety of actors operating on the ground, whose interests do not always converge. West African actors' emic and empirical accents deconstruct some of the prevailing narratives 
and frames of reference, which underlie this migration-development-security nexus and the complex tensions it generates in practice.

The first contribution in this issue focuses on Mauritania. Author Ould Moctar analyzes historical parallels between the colonial encounter and EU border externalization in Mauritania. He highlights how the interrelated domains of territorial delimitation, human mobility, and racialized belonging have been reaffirmed through EU border externalization. Ould Moctar's contribution clearly demonstrates how EU-financed biometric border technologies are used by the Mauritanian government to re-ignite historical and racialized distinctions and exclusions in its southern border zones.

With both contributions of Aguillon and Soukouna, we move on to the description of the global policy framework and the contrasting negotiations it has sparked in the national policy arena in Senegal and Mali respectively. These contributions explore political discourses and narratives as well as how this nexus frames national public debates. Aguillon's contribution looks at the confrontation of narratives in Senegal by examining how international organizations handle critical and divergent postures, and how different actors - from political decision makers to experts, academics and civil society actors justify their involvement and make sense of their contributions. Her article nuances the unidirectional postulate of control and submission of Senegalese actors to external EU dictates. In the following paper, Soukouna outlines the issues, narratives and negotiations surrounding the failure of the signature of the French readmission agreement between 2006 and 2010 in Mali. Her contribution underlines the unusual path of opposition taken by the Malian state against the French state by showing the evolution of migration governance in Mali, and the role played by non-state actors such as the Malian diaspora and civil society. Both authors underline the agency and the evolving positioning of different actors engaging with this global policy framework, showing that national policy preferences are driven by domestic as well as international and transnational factors, albeit to diverging degrees.

Not surprisingly, in view of the density of policies and EU focus on Niger, we have three contributions that explore the multidirectional effects of externalization policies in Niger, and more specifically on the micro-level of three towns (Zinder, Agadez and Niamey). First, Lambert's contribution looks at the asylum procedure in Niger that was recently reinforced as a complementary mechanism of protection and fixation, with support from the EU and the UNHCR. The author investigates what some of these reconfigurations meant to the affected bureaucrats in relevant asylum institutions in Niamey and how the changes were coped with, depending on local interests of citizens in Agadez. Second, Boyer, Tinni and Mounkaila describe how migration became a theme of public action in Niger and how public and private actors are locally engaging with, and reshaping, this new policy framework. The contribution analyzes the political game of these local actors navigating between national narratives and international incentives, while developing opportunistic strategies. Finally, Dauchy investigates how the anti-trafficking law adopted in 2015 in Niger impacted the daily work of Nigerien judicial authorities in relation to their cooperation with, and support from, actors in the field of international justice and security 
reinforcement. Her article highlights that beyond its function of fighting against irregular migration towards Europe, the law also frames migration as a security threat and is, as such, part of a larger strategy for the Nigerien state to strengthen its authority vis-à-vis both citizens and the global geopolitical stage. These three contributions empirically confirm the fact that Niger's current president can be considered as the flagship example of performatively targeting migrants and arresting smugglers in order to receive EU funding and economic support (Brachet, 2018), to subvert and manipulate such interventions for personal gain (Keen and Andersson, 2018), mainly strengthening sovereignty (Brachet, 2011; Dedieu, 2018; Schöfberger, 2019) and international rather than local legitimacy.

Finally, the last three contributions give insight into how externalization policies have increased the use of violence and have themselves exacerbated vulnerabilities, racialization and unequal power relations that migrants are exposed to both in Africa and Europe. Sylla's contribution describes the historicity of Malians' deportation from Libya and the political instrumentalization of migration in national and interregional economic and security policies during and after the Gaddafi era. Sylla demonstrates how the complexity of the current situation in Mali owes much to the historical making (and neglect) of the rights of these "returnees" as Malian citizens. Tyszler's contribution focuses on how the masculinities and femininities of racialized African migrants are reconfigured in interactions between migrants and security agents at the gates of the enclaves of Ceuta and Melilla of the Moroccan-Spanish border. She gives an in-depth understanding of the current consequences of migration policies, which have increased and stimulated racist, sexist, and sexual violence in daily interactions at border hotspots. The last contribution has the peculiarity of being located in Belgium, at the heart of the EU. As in many other European countries, since 2015, a number of extremely vulnerable migrants have arrived on Belgian soil. Elsa Mescoli, Antoine Roblain and Pieter Griffioen describe the ways in which the action of Belgian citizens hosting and helping undocumented Sub-Saharan migrants within a humanitarian framework is progressively politicized. The article contributes interesting insights on the idea of solidarity, which can carry political claims and paternalist rationales. The authors address the spaces and forms of speaking up by migrants within these dynamics, and the process of their politicization. These three last contributions thus explore how the migration-development-security nexus contributes to reshaping collective and individual political subjectivities in highly precarious contexts on both continents.

Drawing on the insights of the contributions to this special issue, our conclusions underline firstly that the foregrounding of "African voices" brings a much needed grounding of policy talk in everyday complexities that, in turn, seriously question Eurocentric ideas of control, management, dominance, presence, and efficiency. Much of the ways in which the interlocutors in this issue speak back to the dynamics and discourses of migration and security demonstrate how EurAfrican borders (Gaibazzi et al., 2017) are emerging, as the products of European and African racialized asymmetric power relations rooted in entangled histories and imperial imaginations of expansionist projects. Both African state and non-state actors actively participate in this migration-development- 
security nexus, at times openly challenging it, and questioning EU-centric ideologies of migration management and control. At other times, we see how cooperation with the EU occurs in tandem with exercizing sovereignty and advancing West African states' influence, especially since security interventions create new enduring institutions that implicate both the private and public sectors. Furthermore, securitization processes go beyond the realm of defense and into the realm of upholding social order by integrating security practices from civilians who simultaneously participate in policing and management while also potentially challenging their domination (Frowd and Sandor, 2018; several contributors in this issue). Thus, new issues, practices, subjects, spaces, as well as collective and individual subjectivities, emerge from this nexus that question Eurocentric responses to migration, which reduce it to either security and/or humanitarian needs. For a long time, African governments have been relatively indifferent towards migration due to the economic benefits it brings. This attitude of indifference is no longer tenable in the face of global politicization of migration and, more specifically, EU pressure and funding.

Secondly, the different contributions in this issue clearly demonstrate that there is a whole range of very differently positioned actors, from presidents to bus drivers, and from asylum bureaucrats to biometric border bureaucrats, covering a wide range of potential responses and interactions. Indeed, the contributions in this volume recount how African actors adopt different types of strategies, ranging from anticipation, incorporation, passive acceptance, and outright opportunism, to partial or total resistance. In so doing, they challenge and give nuance to the image of a single imperial, neo-colonial and/or dominant EU neighborhood approach and discourse. Strongly heterogeneous, the performed opinions, discourses, and tactics thus differ according to positionality in terms of gender, age, class, geographical locality, and occupational position. Thus, as Tyszler (this issue) also demonstrates, this nexus not only reorders space and sovereignty, but it also produces race, class, and gender on both continents. Moving beyond the identification and description of the violence and stigma experienced by African migrants only, this issue investigates the (subversive) strategies and expressive modes of implicit or explicit mobilization, and protest on both an individual and collective level, by a wide variety of African actors who are implicated in the migration industry in different capacities.

Finally, Ould Moctar (this issue) points to the need for more decolonial research on the migration-development-security nexus. On the one hand, studies should expose the more deep-seated historical processes in order to question the colonial encounter and its effects on both colonized and colonizing societies. On the other hand, this also requires highlighting the agency of African actors engaged with this nexus, and to move beyond representations of their participation as mere passive recipients. Reversing the gaze is thus not necessarily showing how European discourse is distortive and resisted. Rather, it consists of describing how daily performative acts have transformative effects on the actual and wished for impacts of policy. 


\section{Bibliography}

Agier M., 2008, Gérer les indésirables : des camps de réfugiés au gouvernement humanitaire, Paris, Flammarion.

Agier M., 2013, La condition cosmopolite. L'anthropologie à l'épreuve du piège identitaire, Paris, La Découverte.

Aguillon M.D., 2018, “Encouraging 'returns', obstructing departures and constructing causal links: the new creed of Euro-African migration management", Migrating out of Poverty, University of Sussex, Working Paper 54, pp. 1-22.

Andersson R., 2014, Illegality, Inc. Clandestine Migration and the Business of Bordering Europe, Oakland, University of California Press.

Awenengo Dalberto S., Banégas R., Cutolo A., 2018, "Biomaîtriser les identités ? État documentaire et citoyenneté au tournant biométrique", Politique africaine, n 152(3), pp. 5-29.

Bayart J.-F., Mbembe A., Toulabor C., 2008, Le politique par le bas en Afrique noire, Paris, Karthala.

Bensaâd A. (dir.), 2009, Le Maghreb à l'épreuve des migrations subsahariennes. Immigration sur émigration, Paris, Karthala.

Bonnecase V., Brachet J., 2013, “Les 'crises sahéliennes' entre perceptions locales et gestions internationales", Politique africaine, $n^{\circ} 130(2)$, pp. 5-22.

Brachet J., 2009, Migrations transsahariennes. Vers un désert cosmopolite et morcelé (Niger), Bellecombe-en-Bauges, Éditions du Croquant.

Brachet J., 2010, “Le jeu des frontières sahariennes”, Plein droit, n 87(4), pp. 20-23.

Brachet J., 2011, "The Blind Spot of Repression: Migration Policies and Human Survival in the Central Sahara", in T.-D. Truong, D. Gasper (eds.), Transnational Migration and Human Security: The Migration-Development-Security Nexus, New York, Springer, pp. 57-66.

Brachet J., 2018, "Manufacturing Smugglers: From Irregular to Clandestine Mobility in the Sahara", The ANNALS of the American Academy of Political and Social Science, $\mathrm{n}^{\circ}$ 676(1), pp. 16-35.

Bréda C., Deridder M., Laurent P.-J. (dir.), 2013, La modernité insécurisée. Anthropologie des conséquences de la mondialisation, Louvain-la-Neuve, Academia-L'Harmattan, 470 p.

Bredeloup S., 2012, "Sahara Transit: Times, Spaces, People”, Population, Space and Place, $\mathrm{n}^{\circ} 18(4)$, pp. 457-467.

Bredeloup S., 2013, "The figure of the adventurer as an African migrant", Journal of African Cultural Studies, $\mathrm{n}^{\circ} 25(2)$, pp. 170-182.

Bredeloup S., 2017, “Migratory Adventure as Moral Experience”, in N. Kleist, D. Thorsen (eds.), Hope and Uncertainty in Contemporary African Migration, New York, London, Routledge Studies in Anthropology, Routledge, pp. 134-153.

Bredeloup S., Pliez O. (dir.), 2005, “Migrations entre les deux rives du Sahara”, Autrepart, n³6(4), pp. 3-20.

Bouilly E., 2008, Les enjeux féminins de la migration masculine. Le Collectif des femmes pour la lutte contre l'immigration clandestine de Thiaroye-sur-Mer, Politique africaine, n 109(1), pp. 16-31. 
Campesi G., 2018, "Crisis, migration and the consolidation of the EU border control regime", International Journal of Migration and Border Studies, $\mathrm{n}^{\circ} 4(3)$, pp. 196-221.

Cassarino J.P., 2018, "Beyond the criminalization of migration: A non-western perspective", International Journal of Migration and Border Studies, $n^{\circ} 4(4)$, pp. 397-411.

Collyer M., De Haas H., 2012, "Developing Dynamic Categorisations of Transit Migration", Population, Space and Place, $\mathrm{n}^{\circ} 18(4), \mathrm{pp} .468-481$.

Courtin C., 2007, "Le codéveloppement : un alibi pour des politiques migratoires restrictives", Revue internationale et stratégique, $\mathrm{n}^{\circ}$ 68(4), pp. 43-47.

Crawley H., Blitz B.K., 2019, “Common agenda or Europe's agenda? International protection, human rights and migration from the Horn of Africa", Journal of Ethnic and Migration Studies, $n^{\circ} 45(12)$, pp. 2258-2274.

Daum C., 2007, "Le codéveloppement, grandeur et décadence d'une aspiration généreuse", Revue internationale et stratégique, $n^{\circ} 68(4)$, pp. 49-59.

Dedieu J.-P., 2018, "The Rise of the Migration-Development Nexus in Francophone Sub-Saharan Africa, 1960-2010", African Studies Review, n 61(1), pp. 1-26.

De Genova N., 2013, "Spectacles of Migrant 'Illegality': The Scene of Exclusion, the Obscene of Inclusion", Ethnic and Racial Studies, n 36(7), pp. 1180-1198.

De Genova N., 2017, “The 'Migrant Crisis' as Racial Crisis: Do 'Black Lives Matter' in Europe?”, Ethnic and Racial Studies, ${ }^{\circ} 41(10)$, pp. 1765-1782.

Den Hertog L., 2016, "Money Talks: Mapping the funding for EU external migration policy", CEPS paper in Liberty and Security in Europe, CEPS, Brussels, November, $58 \mathrm{p}$.

Devillard A., Bacchi A., Noack M., 2015, "A Survey on Migration Policies in West Africa”, IMPCD, IOM, Vienna, Dakar, March, 339 p.

D'Haenens L., Joris W., Heinderycks F. (eds.), 2019, Images of Immigrants and Refugees in Western Europe: Media Representations, Public Opinion and Refugees' Experiences, Leuven, Leuven University Press.

Eizenga D., 2019, "Long-term trends across security and development in the Sahel", West African Papers 25, Paris, OECD Publishing, $25 \mathrm{p}$.

European Commission, 2016a, "Towards a new Partnership Framework with third countries under the European Agenda on Migration: Frequently Asked Questions", Fact sheet, Strasbourg, 7 June, https://ec.europa.eu/commission/presscorner/detail/en/MEMO_16_2118 (last access 26 September 2020).

European Commission, 2016b, "Communication from the Commission to the European Parliament, the European Council and the Council. First Progress Report on the Partnership Framework with third countries under the European Agenda on Migration", $\operatorname{COM(2016)~} 700$ final, Brussels, 18 October, 15 p., https://eeas.europa.eu/sites/eeas/files/com_2016_700_f1_communication_ from_commission_to_inst_en_v8_p1_english.pdf (last access 26 September 2020).

European Commission, 2016c, "Communication from the Commission to the European Parliament, the European Council, the Council and the European investment bank on establishing a new Partnership Framework with third countries under the European Agenda on Migration", press release $\operatorname{COM(2016)} 385$ final, Strasbourg, 7 June, 18 p., https://ec.europa.eu/home-affairs/ 
sites/homeaffairs/files/what-we-do/policies/european-agenda-migration/proposalimplementation-package/docs/20160607/communication_external_aspects_eam_towards_ new_migration_ompact_en.pdf (last access 26 September 2020).

European Council Brussels, 15 \& 16 December 2005 Presidency Conclusions, D/05/4, https:// ec.europa.eu/commission/presscorner/detail/en/DOC_05_4 (last access 26 September 2020).

European External Action Service, 7 June 2016, "Migration Partnership Framework. A new approach to better manage migration", Fact sheet, 3 p., https://eeas.europa.eu/sites/eeas/files/ factsheet_ec_format_migration_partnership_framework_update_2.pdf (last access 26 September 2020).

Faist T., 2006, "The migration-security-nexus: international migration and security before and after 9/11", in Y. Bodemann, G. Yurdakul (eds.), Migration, Citizenship, Ethos, New York, Palgrave Macmillan US.

Fassin D., 2010, La raison humanitaire. Une histoire morale du temps présent, Paris, Seuil.

Ferguson J., 2002, "Of mimicry and membership: Africans and the New World Society", Cultural Anthropology, $\mathrm{n}^{\circ} 17(4)$, pp. 551-569.

Frowd P., 2018, Security at the Borders: Transnational Practices and Technologies in West Africa, Cambridge, Cambridge University Press.

Frowd P., Sandor A., 2018, "Militarism and its limits: Sociological insights on security assemblages in the Sahel", Security Dialogue, $n^{\circ}$ 49(1-2), pp. 70-82.

Gabrielli L., 2007, "Les enjeux de la sécurisation de la question migratoire dans les relations de I'Union européenne avec l'Afrique. Un essai d'analyse", Politique européenne, n²2(2), pp. 49173.

Gaibazzi P., Dünnwald S., Bellegamba A., (eds.), 2017, EurAfrican Borders and Migration Management. Political Cultures, Contested Spaces, and Ordinary Lives, New York, Palgrave Mcmillan US.

Garcia-Andrade P., Martin I., Mannashvili S., 2015, "EU cooperation with third countries in the field of migration", study for the LIBE committee, European Parliament, Brussels, $148 \mathrm{p}$.

Geiger M., Pécoud A. (eds.), 2010, The Politics of International Migration Management, London, Palgrave Macmillan.

Geschiere P., 2009, The perils of belonging: autochthony, citizenship, and exclusion in Africa and Europe, Chicago, University of Chicago Press.

Gruffydd Jones B., 2008, "The global political economy of social crisis: Towards a critique of the 'failed state' ideology", Review of International Political Economy, n 15(2), pp. 180-205.

Gutiérrez Rodríguez E., 2018, “The Coloniality of Migration and the 'Refugee Crisis': On the AsylumMigration Nexus, the Transatlantic White European Settler Colonialism-Migration and Racial Capitalism", Refuge, $\mathrm{n}^{\circ} 34(1)$, pp. 6-28.

Hagberg S., 2018, "Beyond regional radars: Security from below and the rule of law in the Sahel", South African Journal of International Affairs, $\mathrm{n}^{\circ} 25(1)$, pp. 21-37.

Hagberg S., 2019, "Performing Tradition while Doing Politics: a comparative study of the dozos and koglweogos self-defense movements in Burkina Faso", African Studies Review, n62(1), pp. 173-193. 
Heller C., Pécoud A., 2018, "Counting migrants' deaths at the border: From civil society counterstatistics to (inter)governmental recuperation", IMI Working Papers Series 143, pp. 20.

Idrissa R., 2019, "Dialogue in Divergence: The Impact of EU Migration Policy on West African Integration: The Cases of Nigeria, Mali, and Niger", report, Friedrich Ebert Stiftung, Bonn, 48 p.

Iskander N., 2010, Creative State: Forty Years of Migration and Development Policy in Morocco and Mexico, Ithaca, NY, Cornell University Press.

Jackson M., 2008, "The shock of the New: on migrant imaginaries and transitions", Ethnos, $\mathrm{n}^{\circ} 73(1)$ pp. 57-72.

Kabbanji L., 2013, "Towards a global agenda on migration and development? Evidence from Senegal", Population, Space and Place, $\mathrm{n}^{\circ}$ 19(4), pp. 415-429.

Keen D., Andersson R., 2018, "Double games: success, failure and the relocation of risk in fighting terror, drugs and migration", Political Geography, n 67, pp. 100-110.

Kleist N., Thorsen D., 2017, Hope and Uncertainty in Contemporary African Migration, New York and London, Routledge.

Korvensyrjä A., 2017, "The Valletta Process and the Westphalian Imaginary of Migration Research", Movements: Journal for Critical Migration and Border Regime Studies, $n^{\circ} 3(1)$, pp. 191-204.

Kunz R., 2013, "Governing International Migration through Partnership", Third World Quarterly, $n^{\circ} 34(7)$, pp. 1227-1246.

Lavenex S., Kunz R., 2008, “The Migration-Development Nexus in EU External Relations", Journal of European Integration, $\mathrm{n}^{\circ}$ 30(3), pp. 439-457.

Lecadet C., 2016, Le manifeste des expulsés. Errance, survie et politique au Mali, Tours, Presses universitaires François-Rabelais.

Lemberg-Pedersen M., 2013, Private Security Companies and the European Borderscapes. The Migration Industry and the Commercialization of International Migration, London, Routledge.

Lemberg-Pedersen M., 2019, "Manufacturing displacement. Externalization and postcoloniality in European migration control", Global Affairs, n 5(3), pp. 247-271.

Lemberg-Pedersen M., Haioty E., 2020, "Re-assembling the surveillable refugee body in the era of data-craving", Citizenship studies, n²4(5), pp. 607-624.

Mazzocchetti J., 2009, Être étudiant à Ouagadougou. Itinérance, imaginaire et précarité, Paris, Karthala.

Mazzocchetti J., 2018, "Des murs pour seule réponse. De l'enfermement des jeunes de quartiers populaires et des migrants", Recherches sociologiques et anthropologiques, n $49(2)$, pp. 91 113.

Mbembe A., 2016, Politiques de l'inimitié, Paris, La Découverte.

McDougall S., Scheele J., 2012, Saharan Frontiers: Space and Mobility in Northwest Africa, Bloomington, Indiana University Press.

Mehta S., 2019, "Immigration panic: how the West fell for manufactured rage", The Guardian, 27 August, https://www.theguardian.com/uk-news/2019/aug/27/immigration-panic-how-thewest-fell-for-manufactured-rage (last access 26 September 2020). 
Nussbaum M.C., 2018, The Monarchy of Fear. A Philosopher Looks at our Political Crisis, New York, Simon \& Schuster.

Nyamnjoh F.B., 2006, Insiders and outsiders: citizenship and xenophobia in contemporary Southern Africa, New York, Zed Books.

Orsini G., 2016, "Securitization as a source of insecurity: a ground-level look at the functioning of Europe's external border in Lampedusa", Studies in Ethnicity and Nationalism, n 16(1), pp. 135147.

Pascucci E., 2017, "The humanitarian infrastructure and the question of over-research: reflections on fieldwork in the refugee crises in the Middle East and North Africa", Area, n 49(2), pp. 249-255.

Pécoud A., 2015, Depolitising Migration: Global Governance and International Migration Narratives, Basingstoke, Palgrave Macmillan.

Pécoud A., 2017, "De la 'gestion' au contrôle des migrations? Discours et pratiques de l'Organisation internationale pour les migrations", Critique internationale, n 76(3), pp. 81-99.

Pian A., 2014, “Des 'maux' de la migration à la promotion du développement local. De l'enjeu d'un cadre discursif", Cahiers d'études africaines, n²13-214, pp. 181-194.

Pichon E., 2020, "Understanding the EU Strategy for the Sahel", European Parliamentary Research Service, Briefing EU Policies - Insight, September, 11 p., https://www.europarl.europa.eu/ RegData/etudes/BRIE/2020/652050/EPRS_BRI(2020)652050_EN.pdf (last access 26 September 2020).

Quijano A., 2000, "Coloniality of Power and Eurocentrism in Latin America", International Sociology, $n^{\circ}$ 15(2), pp. 215-232.

Raineri L., Rossi A., 2017, "The Security-Migration-Development Nexus in the Sahel: A Reality Check", IAI working papers 17, 20 p., https://www.iai.it/sites/default/files/iaiwp1726.pdf (last access 26 September 2020).

Schapendonk J., 2017, "The multiplicity of transit: the waiting and onward mobility of African migrants in the European Union", International Journal of Migration and Border Studies, $n^{\circ} 3(2-3)$, pp. 208-227.

Schmoll C., Thiollet H., Wihtol de Wenden C. (dir.), 2015, Migrations en Méditerranée, Paris, CNRS Éditions.

Schöfberger I., 2019, "Migration: solid-liquid transnationalism? The EU's struggle to find a shared course on African migration 1999-2019", Working paper series, German Development Institute, $42 \mathrm{p}$.

Sørensen N.N., 2012, "Revisiting the Migration-Development Nexus: From Social Networks and Remittances to Markets for Migration Control", International Migration, $\mathrm{n}^{\circ}$ 50(3), pp. 61-76.

Stierl M., 2016, "A Sea of Struggle - Activist Border Interventions in the Mediterranean Sea", Citizenship Studies, $\mathrm{n}^{\circ}$ 20(5), pp. 561-578.

Stock I., Üstübici A., Schultz S.U., 2019, "Externalization at work: responses to migration policies from the Global South", Comparative Migration Studies, $n^{\circ} 7(1)$, pp. 1-9.

Tardis M., 2018, “European Union Partnerships with African Countries on Migration”, Policy paper, Notes de l'Ifri, Paris, Ifri, $48 \mathrm{p}$. 
Tazzioli M., Garelli G., 2018, "Containment beyond detention: The hotspot system and disrupted migration movements across Europe", Environment and Planning D: Society and Space, pp. 1-19.

Tazzioli M., Walters W., 2019, "Migration, solidarity and the limits of Europe", Global Discourse, $\mathrm{n}^{\circ}$ 9(1), pp. 175-190.

Ticktin M., 2014, "Transnational Humanitarianism", Annual Review of Anthropology, $\mathrm{n}^{\circ}$ 43(1), pp. 273-289.

Toaldo M., Barana L., 2016, "The EU's migration policy in Africa: five ways forward", European Council on Foreign Relations, 8 December, https://www.ecfr.eu/article/commentary_the_eus_ migration_policy_in_africa_five_ways_forward (last access 26 September 2020).

Truong T.-D., Gasper D., 2011, Transnational migration and human security: the migration-developmentsecurity nexus, Springer, Heidelberg.

Vaughan-Williams N., 2008, "Borderwork beyond inside/outside? Frontex, the citizen-detective and the War on Terror", Space and Polity, $\mathrm{n}^{\circ} 12(1)$, pp. 63-79.

Venturi B. (ed.), 2017, "The Security-Development-Migration Nexus Revised: A Perspective From The Sahel", FEPS, IAI, Brussels, 170 p., https://www.feps-europe.eu/Assets/Publications/PostFiles/ 598_1.pdf (last access 26 September 2020).

Vigh H., 2009, "Wayward Migration: On Imagined Futures and Technological Voids", Ethnos, $\mathrm{n}^{\circ}$ 74(1), pp. 91-109. 